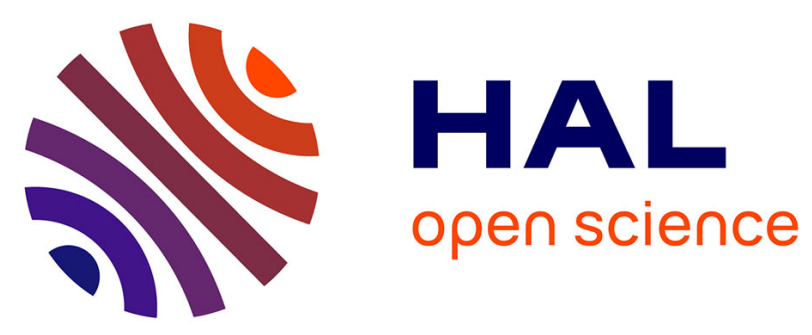

\title{
Investigating fuel poverty in the transport sector: toward a composite indicator of vulnerability
} Audrey Berry, Yves Jouffe, Nicolas Coulombel, Céline Guivarch

\section{To cite this version:}

Audrey Berry, Yves Jouffe, Nicolas Coulombel, Céline Guivarch. Investigating fuel poverty in the transport sector: toward a composite indicator of vulnerability. Energy Research \& Social Science, 2016, 10.1016/j.erss.2016.02.001 . hal-01277414

\section{HAL Id: hal-01277414 \\ https://hal.science/hal-01277414}

Submitted on 22 Feb 2016

HAL is a multi-disciplinary open access archive for the deposit and dissemination of scientific research documents, whether they are published or not. The documents may come from teaching and research institutions in France or abroad, or from public or private research centers.
L'archive ouverte pluridisciplinaire HAL, est destinée au dépôt et à la diffusion de documents scientifiques de niveau recherche, publiés ou non, émanant des établissements d'enseignement et de recherche français ou étrangers, des laboratoires publics ou privés. 
Investigating fuel poverty in the transport sector: toward a composite indicator of vulnerability

A. Berry ${ }^{1 \star}$, Y. Jouffe ${ }^{2}$, N. Coulombel ${ }^{3}$, C. Guivarch ${ }^{1}$

${ }^{1}$ Centre International de la Recherche sur l'Environnement et le Développement, 45 Avenue de la Belle Gabrielle 94130 Nogent-sur-Marne, France, UMR, Ecole des Ponts ParisTech, CNRS, AgroParisTech, EHESS, CIRAD.

2 Université Paris-Est, Lab' Urba, 5 Boulevard Descartes 77420 Champs-sur-Marne, France

${ }^{3}$ Université Paris-Est, Laboratoire Ville Mobilité Transport UMR T 9403, Ecole des Ponts ParisTech, 6 et 8 avenue Blaise Pascal, 77455 Marne-la-Vallée cedex 2, France

* Corresponding author: berry@centre-cired.fr

\begin{abstract}
This paper investigates the issue of fuel poverty and of its measurement in the transport sector. We seek to identify households who run the risk of facing difficulties if fuel prices increase. We show that fuel poverty indicators from the domestic sector are not satisfactory in this regard. They fail to take into account three specificities of the transport sector: (1) the diversity of travel needs, (2) restriction behaviours, and (3) variable capacities to adapt. We propose a composite indicator that targets factors of vulnerabilities. In contrast to the previous indicators, it does not solely focus on budgetary aspects but also reflects conditions of mobility. Three levels of exposition to rising fuel prices are considered, depending on the combinations of factors. We test this indicator on French data and find that $7,8 \%$ of French households are identified fuel poor, a further $7,4 \%$ fuel vulnerable and a further $3,7 \%$ fuel dependent.
\end{abstract}

\title{
Keywords
}

Fuel poverty, vulnerability, transport, measurement

\section{Acknowledgments}

Audrey Berry gratefully acknowledges financial support for part of this study from ADEME and from the Sustainable Mobility Institute from Renault and ParisTech.

DOI: 10.1016/j.erss.2016.02.001

(C2016. This manuscript version is made available under the CC-BY-NC-ND 4.0 license http://creativecommons.org/licenses/by-nc-nd/4.0/ 
Investigating fuel poverty in the transport sector: toward a composite indicator of vulnerability

\begin{abstract}
This paper investigates the issue of fuel poverty and of its measurement in the transport sector. We seek to identify households who run the risk of facing difficulties if fuel prices increase. We show that fuel poverty indicators from the domestic sector are not satisfactory in this regard. They fail to take into account three specificities of the transport sector: (1) the diversity of travel needs, (2) restriction behaviours, and (3) variable capacities to adapt. We propose a composite indicator that targets factors of vulnerabilities. In contrast to the previous indicators, it does not solely focus on budgetary aspects but also reflects conditions of mobility. Three levels of exposition to rising fuel prices are considered, depending on the combinations of factors. We test this indicator on French data and find that $7,8 \%$ of French households are identified fuel poor, a further $7,4 \%$ fuel vulnerable and a further $3,7 \%$ fuel dependent.
\end{abstract}

\title{
Key words
}

Fuel poverty, vulnerability, transport, measurement

\section{Introduction}

Because of climate change policies or depleting fossil fuels, fuel prices are expected to rise and an increasing number of households could face difficulties to afford their energy bills, adequately warm their home and achieve their travel needs. The United Nations has identified the provision of sustainable energy for all as one of the main priority in the "Sustainable Development Goals" that will guide national and global policies to 2030 ("Proposal for Sustainable Development Goals" 2014). Similarly, Sovacool \& Dworkin (2015) refer to the concept of energy justice and define it as "a global energy system that fairly disseminates both the benefits and costs of energy services". This concept is gaining attention and emphasizes the need to implement energy policies that tackle climate change while improving rather than worsening socioeconomic and spatial inequalities. Therefore addressing the issue of fuel poverty, and the vulnerability of households to higher energy prices, is a requisite to pursue on the pathway of deep-decarbonisation of the society.

Attention has been focused on fuel poverty in the domestic sector so far. Traveling by car is another essential energy service for part of the population, (Sovacool et al., 2012 ; Heindl \& Löschel, 2015). High fuel prices can induce restriction behaviours - households do not meet their travel needs - and it may become a barrier to access employment, and cause social and economic exclusion (Orfeuil, 2004). Therefore fuel poverty policies are necessary to accompany fuel prices rises.

The success of fuel poverty policies depends on the capacity to target the most vulnerable population (Dubois \& Meier, 2014). If inadequately targeted, they may miss their intended purpose (Guyet, 2014). Indicators of fuel poverty are thus needed to guide the targeting of policies and measure their impacts. 
In this paper, we focus on the evaluation of fuel poverty in the transport sector. We investigate which indicator(s) are most suitable to measure households' exposition to rising fuel prices in the transport sector. We show that transposition of current fuel poverty indicators used in the domestic sector is not satisfactory, and that it calls for the development of a multidimensional indicator, which combines information on the financial resources, fuel consumption and conditions of mobility.

Existing indicators mainly focus on income and fuel spending - assessing the ability to afford one's fuel bills (Nicolas et al., 2012). Although budgetary constraints are important, they only provide a partial picture of fuel poverty. In line with Sen's poverty approach seen as capability deprivation - lacking the opportunity to achieve some minimally acceptable basic functionings (Sen, 1992) - we interpret fuel poverty in the transport sector as lacking the opportunity to adequately achieve one's travel needs. Travel needs vary from one household to another depending on a variety of geographic, technical and socio-economic characteristics. This variation raises concerns about the adequacy of conditions of mobility in regard with travel needs, as well as with households' capacity to adapt their practices in face of rising fuel prices. We show that existing indicators fail to account for the diversity of travel needs and capacity to adapt, and we develop a novel indicator to do so.

The construction of our indicator, and its comparison with existing indicators, is illustrated with an application to the French case study based on the national travel database ENTD 2008 - Enquête Nationale Transport et Déplacement.

The rest of this paper is structured as follows. Section 2 reviews indicators of fuel poverty in the domestic sector. Section 3 describes specificities of the transport sector that have to be considered for evaluating fuel poverty in the transport sector. Section 4 describes the methodology to build indicators measuring fuel poverty in the transport sector. Section 5 presents the survey data for the application to the French case study. Section 6 presents the results and discusses the different indicators. Section 7 concludes.

\section{Measuring fuel poverty in the domestic sector: a review of current indicators}

\subsection{Definition and measurement issues}

A household is said to be in fuel poverty when its members are unable to afford to keep adequately warm at reasonable cost. This original British definition generalizes to the situation of a household whose members are unable to afford an adequate amount of energy services to satisfy their basic needs, as mentioned in the legal French definition. ${ }^{1}$ This definition may include other domestic uses than ambient heat and hot water, as the rising uses of home appliances. Tackling vital warmth and socially constrained uses together raises justice issues. Concepts of energy justice emerge to elaborate relevant public policies related to energy services (Sovacool and Dworkin, 2015). Transportation is sometimes included within the scope of energy justice, especially through the global South oriented concept of energy poverty (Sovacool et al., 2015). While warmth needs may rely on physiological parameters though some socio-cultural dimensions (Subrémon, 2011), transport belongs to the energy needs that are mainly constrained by social arrangements. This specificity of

\footnotetext{
${ }^{1}$ See the Loi Besson du 31 mai 1990 : http://www.legifrance.gouv.fr/affichTexte.do?cidTexte=LEGITEXT000006075926\&dateTexte=vig
} 
transportation and others that will be detailed below, call for a "vulnerability" approach towards planning policies, more than a "poverty" approach that targets households already facing difficulties within the vicious circle of poverty (Bouzarovski \& Petrova, 2015). A wider scope of fuel poverty implies its very reconceptualization towards a possible change of policy approach. A common agreement has emerged to identify low income, poor energy performance, and high fuel costs as the key drivers of fuel poverty (Palmer, G., Maclnnes, T., Kenway, P., 2008., n.d.)). Location is also identified as a key defining feature (Thomson \& Snell, 2013) (Roberts, Vera-Toscano, \& Phimister, 2015). However these definitions relate to the domestic energy. Similarly we propose to define fuel poverty in the transport sector as involving the following three drivers: low income, high fuel costs and poor conditions of mobility. Conditions of mobility refer to the accessibility to jobs and services, to the existence of other modes of transport - than private vehicle - to reach them, and to the energy performance of the vehicle, be it cars or two-wheelers. From this definition, fuel poverty shows different dimensions - namely economic, technical and geographic - and reflects different situations. The particular situation of each household depends on its lifestyle, its budget and its preferences, as well as on external factors. To illustrate, some households may face difficulties to meet their travel needs because of budgetary constraints, while others because of an inappropriate spatial matching associated with long travel time, high fuel spending or physical tiredness of traveling (Nicolas et al., 2012). Some households may be forced to adjust their behaviours and restrict their mobility, meaning they may reduce their number of trips. This raises concerns in regard with households' accessibility to employment areas, to healthcare centres or other critical motives (Gaschet and Gaussier, 2005; Aguilera and Mignot, 2003). Others may develop different strategies to cope, they may prefer to give up on other essential spending, such as food or clothing, in order to keep satisfied their travel needs

This variety of situations rouses debates about which indicator(s) should be used to evaluate fuel poverty. In the domestic sector, several studies showed that the depiction of fuel poverty may substantially vary depending on the indicator chosen, be it in terms of the number or of the categories of households concerned (Ricci \& Bérangère, 2014; Waddams et al., 2012; Valbonesi et al., 2014; Walker et al., 2014) This choice is not trivial; indicators are not neutral in their approach to fuel poverty, but points out to different political representations of the problem. It is necessary to reach a shared representation of fuel poverty, involving a common definition and consensual indicators (Chancel et al., 2015). Actually it is a requisite for fuel poverty policy to be effectively designed and implemented, because indicators are the basis on which to quantify the extent of the problem, to identify the affected population and to design mitigation policies (Hills, 2012a; Moore, 2012; ONPE, 2014). Because fuel poverty is multidimensional, reducing fuel poverty only to budgetary aspect does not account for the more complex reality of the phenomenon, so that a good fuel poverty indicator should be enlarged to integrate information on the living conditions. Though we acknowledge both housing and mobility aspects should be considered, in this paper we focus on the transport dimension of fuel poverty. Thus information is needed on the financial resources of the households, on their car fuel consumption ${ }^{2}$ as well as on their conditions of mobility. This suggests that a good indicator should capture the difficulties to afford one's car

\footnotetext{
${ }^{2}$ Because two-wheelers are few compared to cars, we use « car fuel consumption » to refer to both car and two-wheelers fuel consumption.
} 
fuel bills as well as situations of restriction, and that it should assess the level of energy performance as well as the implications of one's residential choice.

\subsection{Ratio indicator}

Fuel poverty in the domestic sector is commonly measured with the $10 \%$ ratio indicator, which was first introduced in the UK in the 1990s. A household was said to be in fuel poverty if it needs to spend more than $10 \%$ of its disposable income on energy services (Bradshaw and Hutton, 1983; Boardman, 1991). Rather than actual energy spending, the energy spending was estimated from the energy required to provide satisfactory heating depending on the household type and level of occupancy - plus adequate lighting, hot water, cooking and typical appliance use (DETR, 2000). Alternatively the energy spending can be based on domestic energy bills and relate to actual energy spending. The $10 \%$ threshold was defined as twice the median energy spending at that time in the UK, which was considered an unreasonably high spending. This threshold has since been kept at $10 \%$, despite variations in the median energy spending, making this ' $10 \%$ ' an arbitrary value. Analogously to poverty measurement in the European Union and the OECD, the threshold can be defined in relation to the current situation as twice the current median ratio (ONPE, 2014). The emphasis is then put on relative fuel poverty, as the number of fuel poor is influenced by the distribution of fuel spending among the whole population and relates to the way of life of the society in which they live. While a relative threshold may better gauge the extent of disproportionate spending, it masks the fact that significantly more households will have real difficulty in meeting their fuel spending in face of rising fuel prices - the number of fuel poor remaining the same whatever the level of energy prices (other things being held equal). The recent high volatility of fuel prices makes this relative measure questionable. Using a ratio indicator also has the disadvantage to include households that are not poor. However, it clearly highlights out of ordinary situations. In this paper, we use the term ratio indicator to refer to both approaches (fixed or relative threshold).

\subsection{LIHC indicator}

More recently, a new indicator has been developed by Hills (2012b), still for the UK. The Low Income High Cost (LIHC) identifies households having both a high fuel spending and a low income (Hills, 2012b). Fuel spending is based on an estimated energy requirement, and not an actual energy spending. The advantage is to eliminate the restriction bias. A household who under consumes might not be identified if actual spending is used, whereas using required spending tells us about what this household would actually spend if it were not to restrict its consumption. The estimated fuel spending is adjusted either to the size of the dwelling or to the household composition. The former represents the energy efficiency of the home (energy spent per square meter) and the latter the level of occupancy (equivalisation of the fuel spending according to the household composition). The adjusted fuel spending is then compared to the corresponding national median. It is interesting to note that this threshold can be interpreted as a norm - being the mean energy efficiency and the mean energy spending per household composition. Each household can be compared to this norm independently of its revenues, and it offers some information on the adequacy of their conditions of housing. However taking the median spending as the threshold for reasonable costs makes the literal eradication of fuel poverty highly challenging (if not impossible), and it may not adequately reflect improvements in the energy efficiency and fuel costs of targeted homes. Regarding the income, it is expressed as the equivalised disposable income after 
housing costs, also known as the equivalised residual income. Loans, mortgage and rents are deduced from disposable income, so that it better reflects the purchasing power of a household and its actual capacity to afford its energy bills after housing costs. To compare the standards of living of households of different sizes or compositions, the residual income is then adjusted by the number of consumption unit (CU) using the OECD equivalence scale: 1 $\mathrm{CU}$ for the first adult in the household, $0.5 \mathrm{CU}$ for other adults, $0.3 \mathrm{CU}$ for children. This equivalised residual income is then compared to a threshold set at $60 \%$ of the national median equivalised residual income (after housing costs) plus their estimated fuel spending after equivalisation. This threshold is in line with relative income poverty measurement used in the European Union (Eurostat). Finally a household is identified as being fuel poor if it cumulates both constraints - a high required energy spending and a low residual income. One drawback of this approach is that it is excessively complex, making it more difficult to calculate than a ratio indicator, especially if the latter is based on actual energy spending. It is also more difficult to interpret - as a result of its equivalisation of fuel costs and redundancy of fuel costs in the income and fuel dimensions.

\section{Specificities of the transport sector}

This section discusses three specificities of the transport sector relatively to the domestic sector with regard to fuel spending. The underlying research question, which will be more specifically addressed in the next section, is whether indicators of fuel poverty from the domestic sector are also relevant to the transport sector, and whether they may be directly transferred or some adjustments are necessary.

\subsection{Highly diverse travel needs}

Mobility has become essential to access employment and services as well as for social inclusion. While some trips are undoubtedly more necessary than others, it is difficult to provide a clear and well-delimited definition of this "required travel" (unlike for housing). Generally speaking, travel needs refer to all trips necessary for good inclusion in society. One may think of the following purposes in particular: work, studies, health, administrative services, shopping or visits to family and friends.

Setting aside the complexity of precisely defining travel needs, another significant hurdle in the transport sector arises when trying to specify a standard car fuel consumption, defined as the quantity necessary to fulfil those basic travel needs (Rao and Baer, 2012). Distances to reach doctors, to visit family, and to go to work or study depend on a number of factors involving the transport system, the system of activities, as well as the personal situation of the household, so that designing a minimum travel need - be it in distance, energy, or euros - is hardly relevant at an aggregate level. We analyse car fuel spending for commuting among French households to exemplify this point ${ }^{3}$. The distribution is very spread, whatever the income quartile (Figure 1). Although the median spending for commuting by car is only $2.8 €$ per day, a substantial share of the population spends more than $10 €$ per day, that is four times the median amount. This high variability reflects the

\footnotetext{
${ }^{3}$ Fuel spending is built from ENTD and relates to commute trips for all members of a household. It is derived from stated distance traveled by car for commuting, the number of trips per day and per week, the efficiency of the car, the type of fuel and the price of fuel.
} 
diversity in households' travel needs, while hindering the definition of a norm for car fuel spending.

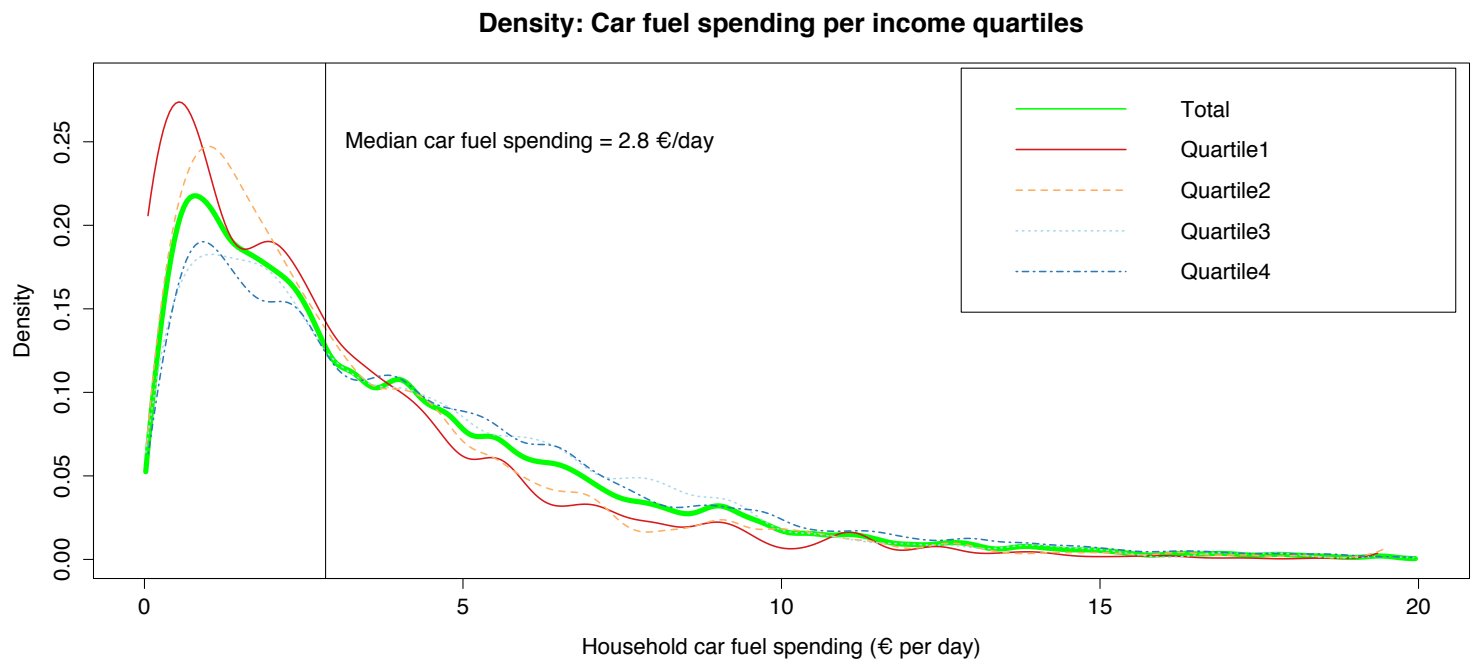

Scope: Total daily fuel spending for commuting, among households with at least one member commuting by car Source: ENTD 2008

Figure 1: Distribution of car fuel spending per income quartile

Given these considerations, one might seek to estimate a standard car fuel spending specific to each household. The value would be derived with a model that would consider the various characteristics of the household, as in the LIHC methodology (see subsection 1.3). Again, the strong heterogeneity of travel behaviours makes the development of such a model - with a sufficient level of accuracy - unlikely, even in the medium run. To illustrate, car use is strongly influenced by residential location. Commuting distances and subsequently distances travelled by car strongly increase the further one lives from the city centre (Berri, 2007; Coulombel and Leurent, 2013). This average trend conceals a wide variety of individual situations that cannot be overlooked, however. To elaborate, we computed the total daily kilometres travelled by car per household for commuting, among active households using the $\mathrm{car}^{4}$. We find the median commuting distance is $50 \mathrm{~km}$ per day for households living in rural areas, which is $16 \%$ more than in small urban areas (43 km per day) and almost twice more than in large urban areas (26 km per day). This being said, $28 \%$ of rural households travel more than $80 \mathrm{~km}$ per day (respectively $25 \%$ for small urban areas and $10 \%$ for large urban areas), while $17 \%$ travel less than $20 \mathrm{~km}$ per day (30\% and $40 \%$, respectively). Disparities are therefore greater within a same geographical area than between two different areas, confirming that travel needs significantly vary among otherwise similar households. If we managed to define normative fuel spending for essential services in the house, this might not be the case for daily travel (Jouffe and Massot, 2013).

Fuel poverty policies must target the most vulnerable households to be effective. Because of the diversity of travel needs, one can reasonably raise concerns that in the transport sector, targeted measures based on averages could lead to significant errors of

\footnotetext{
${ }^{4}$ Data is drawn from the French National Transport Survey 2008 (the latest available at the time of writing).
} 
inclusion and exclusion, and ultimately prove counterproductive. ${ }^{5}$ Similarly, a normative approach of travel needs at the household level is unlikely for the years to come. Indicators of fuel poverty in the transport sector should therefore rely on actual spending - instead of estimated spending as in the LIHC methodology - while taking the diversity of travel needs into account.

\subsection{Differing forms of restriction}

To address fuel poverty in the transport sector, what matters is to understand variations in travel practices and to focus on detecting situations at-risk. Restriction, defined as limiting the use of one's private vehicle due to budget constraints, is likely the most common and prejudicial symptom. If the household transport budget is relatively stable across income levels in absolute value, it represents a high fraction of income for the less well-off households. Some of these are forced to constraining adjustments accordingly, leaving part of their travel needs unsatisfied (Orfeuil, 2004). This may limit access to job opportunities and essential services, or preclude visits to family and friends. Over time, it might lead to social exclusion and prevent these households from fully participating in the economic, social, and political life of the society they live in.

Yet, having a low motorised mobility is not problematic in itself, for two reasons. Households may have low travel needs: some people work from home, while others prefer to get their shopping delivered at home rather than going to supermarkets. Again, this is to relate to the high diversity of travel needs discussed previously. Furthermore, households may willingly use other modes of transport. They may have access to an extensive and rapid public transport system, or prefer active modes (walking, cycling) as a way to do physical exercise. ${ }^{6}$ On the other hand, households who use public transit because of the excessive cost of car can be in a disadvantageous situation when it implies much longer travel times, for instance. These arguments bring out the importance to distinguish between actual restriction, low mobility and low motorised mobility.

Conversely, restriction can also affect households with high travel mobility. Again, some households have higher motorised travel needs than others, typically those living in the furthest parts of the metropolitan area or bi-active households. Both situations imply longer distances than average to meet yet essential needs. When there is no other mode (than car) accessible, it may lead to an excessively high fuel spending, so that these households ultimately have to restrict their trips. Because similar travel practices can reflect either preferences or deprivations, it calls for a fuel poverty indicator including a direct evaluation of car use restriction behaviours, as well as an evaluation of the extra travel time induced when using public transit compared to using car.

\subsection{Adaptive behaviours}

Another key difference with the housing sector is the presence of alternatives in the transport sector. Public transit, walking and cycling are substitutes for car use. The last two

\footnotetext{
${ }^{5}$ Such measures would risk not helping some of the most vulnerable households in achieving their travel needs, while encouraging other households - those with low travel needs - to drive longer distances by car.

${ }^{6}$ This is especially the case for urban households, who may be highly mobile without owning a car through multimodal behaviours.
} 
requiring no energy (other than muscular) and public transport being less energy intensive than the car, households may use these modes of transport to mitigate the impact of a sharp increase in fuel prices without limiting their trips. These alternatives are not spatially equally distributed and thus not available to all households, however (Jones and Lucas, 2012). Households living in suburban and rural areas seem especially vulnerable in face of increasing fuel prices (Saujot, 2012; Huyghe, Baptiste, \& Carrière, 2013). Even when other modes are available besides the car, they might not always meet one's travel needs without leading to excessive travel time or inflicting too much hardship. One might think of disabled people, crowded buses or the need to transfer three times before reaching one's workplace.

Though we recognise that using the car may be a choice, it can also be a source of dependency when no alternative is available, making households especially vulnerable to future rises in fuel prices. Our point is that if alternatives to car exist, they may not be evenly available, and households may be unequal in their capacity to adapt in face of rising fuel prices. Because similar practices of car use can reflect either a choice or a dependency to this mode, a good fuel poverty indicator ought to evaluate the availability of suitable alternatives with regard to the household's travel needs.

\section{Toward a new indicator for the transport sector}

To diagnose fuel poverty in the transport sector, the first idea would be to transpose existing indicators used in the domestic sector to the transport sector. However, we will show why they are not entirely satisfactory in the transport sector, leading us to propose a new indicator. Derived from multidimensional poverty measurement, our composite indicator intends to better take the specificities of the transport sector in consideration.

\subsection{Transposition of the domestic indicators}

\subsubsection{Ratio indicator}

The ratio indicator identifies households with an excessive fuel spending in relation to their income. There exists some variations in the literature regarding the following aspects: figures expressed per household or per unit of consumption, modelling of travel distances and spending, trip purposes included, and thresholds (Cochez et al. 2015 ; Nicolas et al., 2012 ; Lovelace, 2013). One usual concern underlying the choice of the ratio indicator is when combined with fuel poverty in the domestic sector (Rouxel, 2015 ; Alterre Bourgogne, 2007). Several variations of the ratio indicator in the transport sector were also tested at the scale of the Paris region (Beaufils et al., 2014).

In our paper, we choose the following definition of the ratio indicator:

$$
\text { Ratio }=\frac{\text { Fuel spending }}{\text { Income }}
$$

Fuel spending and income are both measured at the household level. Analogously to the domestic sector (see subsection 1.2) a household is considered at risk if its ratio is over twice the median ratio.

\subsubsection{The Low Income High Cost (LIHC) indicator}

The LIHC indicator is a two-dimensional indicator that identifies households who have a high fuel spending and a low income. It was recently applied to the city of Strasbourg for 
both housing and transport (Mayer et al., 2014). Fuel spending is expressed per person or per consumption unit for transport (CUt). Depending on the type of travel studied (scope and nature of trip purposes), an equivalence scale may be appropriate, for which members of a household receive different weightings. Total household fuel spending is then divided by the sum of the weightings to yield a representative fuel spending - the fuel spending per CUt and enable meaningful comparison across households.

$$
\text { Fuel spending per person or CUt }=\frac{\text { Fuel spending }}{\text { Number of persons or CUt }}
$$

Regarding income, we consider the residual income after fuel spending. It is adjusted by the number of consumption unit for income (CUi) in the household, using the OECD equivalence scale ${ }^{7}$.

$$
\text { Residual } i \text { come per } C U i=\frac{\text { Income }- \text { Fuel spending }}{\text { Number of } C U i}
$$

A household is considered fuel poor if its fuel spending per person or CUt is higher than the median, and if its residual income per consumption unit is lower than the poverty line (60\% median income per CUi).

\subsection{Limitations of the domestic indicators}

As we have just seen, both indicators are based on actual fuel spending: while the ratio indicator also often uses actual fuel spending in the domestic sector, in the case of the LIHC indicator, this stems from the specificities of the transport sector. Accordingly, they cannot detect restriction behaviours and do not inform the adequacy of households' conditions of mobility. Moreover, both indicators fail to consider two other key aspects of the transport sector, namely the diversity of travel needs and the variability of households' adaptive capacities in face of a sudden rise in fuel prices. Because all these points are at the crux of fuel poverty issues, we recommend using an alternate approach that directly measures the factors of vulnerability.

Vulnerability can be defined as "the ability or inability of individuals or social groupings to respond to, in the sense of cope with, recover from or adapt to, any external stress placed on their livelihoods and well-being" (Kelly \& Adger, 2000). ${ }^{8}$ In this paper we understand fuel vulnerability as the degree to which a household is likely to experience difficulties due to exposure to rising fuel prices. Working Group II to the Fifth Assessment Report of the Intergovernmental Panel on Climate Change points out that "vulnerability encompasses a variety of concepts and elements including sensitivity or susceptibility to harm and lack of capacity to cope and adapt."

To assess vulnerability, we consider vulnerability as a combination two elements:

- Sensitivity is the degree to which something/someone is affected by exposure to stress.

\footnotetext{
${ }^{7}$ In the OECD equivalence scale, the weighting of the different members of a household are: 1 $\mathrm{CU}$ for the first adult in the household, $0.5 \mathrm{CU}$ for other adults, $0.3 \mathrm{CU}$ for children

${ }^{8}$ See also on this topic (Bohle, Downing, \& Watts, 1994), (Adger, 2006), (Büttner et al., 2012).
} 
- Adaptive capacity is the ability of something/someone to adjust to potential damage, to take advantage of opportunities, or to respond to consequences.

We therefore build a composite indicator combining an assessment of households' financial resources, mobility practices and conditions of mobility. Derived from multidimensional poverty measurement, this indicator consists of several factors, which can be economic, technical, geographical or cross dimensional. The composite indicator reflects the adequacy of one's situation and aims at identifying multiple combinations of factors translating into an exposition to rising fuel prices.

\subsection{A composite indicator}

The composite indicator identifies households cumulating different unfavourable factors exposing them to a rise in fuel prices. Derived from multidimensional poverty measurement (UNDP, 2014), the composite indicator combines an assessment of financial resources, an assessment of mobility practices and an assessment of households' conditions of mobility. It is composed of several factors, which can be of economic, technical and geographic nature, that are combined into a single indicator. It is built to allow those individual factors to be combined in a manner, which reflects the dimensions of the phenomena being measured - vulnerability to rising fuel prices. Similarly to the dual cut-off method developed by Alkire and Foster (2011), it employs two types of threshold: one threshold is defined per factor to determine whether that factor applies to the household, and the other threshold is defined across factors to identify the population exposed to a rise in fuel prices - by cumulating the factors in which a household is affected. Other multidimensional approaches have been used for mapping energy vulnerability (see for instance (Fruchart, 2012)) or transport poverty (Beaufils et al., 2014 ; Sustran, 2012 ; Dodson \& Sipe, 2007). These indicators do not specify the situation characterized by each combination of factors, however, but only use the number of factors as an indication of the risk level with regard to fuel poverty. In this study the composite indicator assesses the adequacy between the main dimensions of fuel poverty and it reflects specific combinations of factors translating an exposition to rising fuel prices. Dimensions and factors are described in Table 1. 
Table 1: Dimensions and factors included in the composite indicator

Dimensions

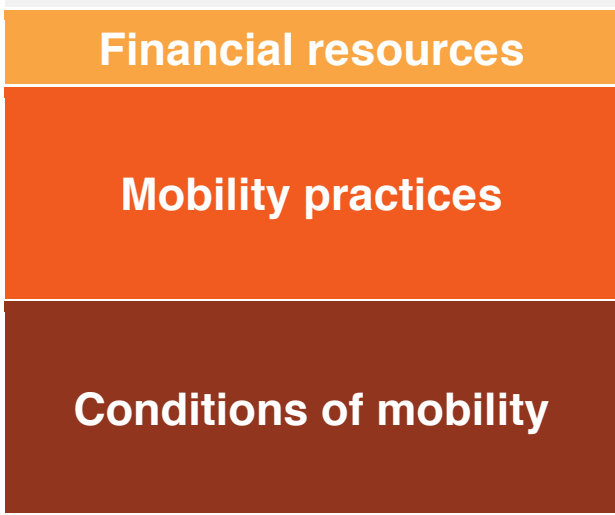

Factors

\begin{tabular}{|c|} 
Low income \\
\hline High fuel spending \\
\hline Extra travel time \\
\hline Car use restriction \\
\hline Poor spatial matching \\
\hline No alternative \\
\hline Low vehicle performance or No vehicle \\
\hline
\end{tabular}

Financial resources include a single factor: low income. ${ }^{9}$

- Income reflects the household propensity to afford its travel costs and achieve its travel needs. It is expressed as the income per consumption unit for income (CUi).

Mobility practices is composed of three factors: high fuel spending, extra travel time and car use restriction.

- Fuel spending is expressed per person or per consumption unit for transport (CUt). Similarly to LIHC, it represents the average fuel spending per person or CUt in the household.

- Extra travel time is assessed for households who have at least one member using public transport, because they can be in a disadvantageous situation when it implies much longer travel times. It is expressed per person and it is based on an assessment of the travel time difference induced by using public transport compared to using car.

- Car use restriction reflects a deprivation in one's motorised mobility. Because of budgetary constraints, either one is constrained to use another mode of transport despite his preference for using the car, or he is constrained to cancel part or all of his trips. Because travel needs are diverse (see previous section), an assessment based on actual spending cannot reveal if one meets its required motorised mobility. Therefore restriction is based on statement.

Conditions of mobility are composed of three factors: poor spatial matching, no alternative, and low vehicle performance or no vehicle.

\footnotetext{
${ }^{9}$ The choice of the term "Low income" reflects the fact that one may want to consider a larger category of population than "income poor" households only as is usually the case. As a matter of fact, in the following application in Section 6, we define "Low income" households as ones with income below the median for the composite indicator, instead of using the standard "Income poor" criterion (set at $60 \%$ of the median) as for the ratio and LIHC indicators (see discussion in subsection 6.3)
} 
- Spatial matching is expressed as the average distance travelled per person or CUt in the household. All modes of transport are included, it relates not only to travelled distances by car, but also to active, public transport and car passenger travelled distances. It reflects the proximity (or remoteness) to basic amenities and to households' required activities. It depends on local geographical features and highlights the adequacy of one's residential location choice.

- Alternative reflects the possibility to shift from the private car to other modes of transport. It can be based on declaration, or derived from surveying the alternatives to the private car that are both accessible and adequate to the travel needs of the household.

- Vehicle performance reflects the technical aspects of one's mobility. For households having a vehicle, it is assessed from the technical characteristics of their vehicles. It reflects the engine efficiency, the type of fuel and the horsepower. For households having no vehicle, they are considered at-a-disadvantage in regard with vehicle performance. Not owning a car is not necessarily a disadvantage, but rather depends on the location and the accessibility of alternative transport (for example it is a luxury to have a car in a city such as Paris). This is why this factor will become meaningful only when combined with another factor - among the conditions of mobility. Furthermore non-access to personal vehicle is identified as a key determinant of social inequalities related to mobility for low-income households (Mignot and Aguiléra, 2004), so that we do not want to miss those households but include them in the evaluation.

A household is considered "exposed to rising fuel prices" if it cumulates several factors. Different combinations of factors reveal different situations and exposition to rising fuel prices. More specifically, the composite indicator distinguishes between three levels of exposition to increasing fuel prices: fuel poverty, fuel vulnerability and fuel dependency. Each level of exposition derives from specific combinations of factors (see Table 2).

- Fuel poor are households combining a low income with a high fuel spending and/or restriction. They already face difficulties to afford their mobility, either because they have to spend disproportionate amount of money on buying fuel in regard with their financial resources, or because they already choose to cancel some of their motorised travels for budgetary reason.

- Fuel vulnerable are households characterized by a low income and cumulating at least two disadvantageous conditions of mobility among three - poor spatial matching, no alternative, and low vehicle performance or no vehicle. They show little capacity to adapt so that the limits of their present situation expose them to future difficulties, especially in case of an unexpected change of situation (new-born baby, change workplace, higher housing costs, etc.). They are at-a-disadvantage in their mobility independently of how much they spend on fuel.

- Fuel dependent are households combining a high fuel spending with no adequate alternative mode of transport. They are dependent on driving long distances, so that in front of rising fuel prices, their fuel spending would highly increase and could result in financial stress. This is particularly problematic in the short term as those households show limited leeway in how to adapt, and households with high 
committed spending such as loan reimbursement or payment of children studies could be negatively affected in their daily budget.

Elements of the composite indicator inform on the sensitivity and adaptive capacity of households to rising fuel prices. Both dimensions being interlinked, it is difficult to separate out variables for sensitivity from variables for adaptive capacity - for example having a low income translates being more impacted by a high fuel spending, and also being more limited in one's capacity to adapt, by affording a new efficient car or by relocating closer to one's workplace. The variables of the composite indicator aim at qualifying different levels of difficulties in households' mobility, so that they are essentially focus on assessing the sensitivity of households. The difficulty in defining the mobility needs (subjectivity, sociospatial constraints, tactics or various strategic alternatives) forces us to rely on three types of data, namely the mobility practices, conditions of mobility and financial resources. Considering the conditions of mobility and the financial resources also sheds light on the ability to cope and adapt, and in particular it emphasizes the specificity of fuel dependent. Therefore there is some assessment of adaptive capacity, but this is rather an additional insight enabling to define more or less sensitive groups of households, and calling to different types of preventive measures. A more comprehensive consideration of adaptive capacity remains to be done, in a conceptual framework to be adapted.

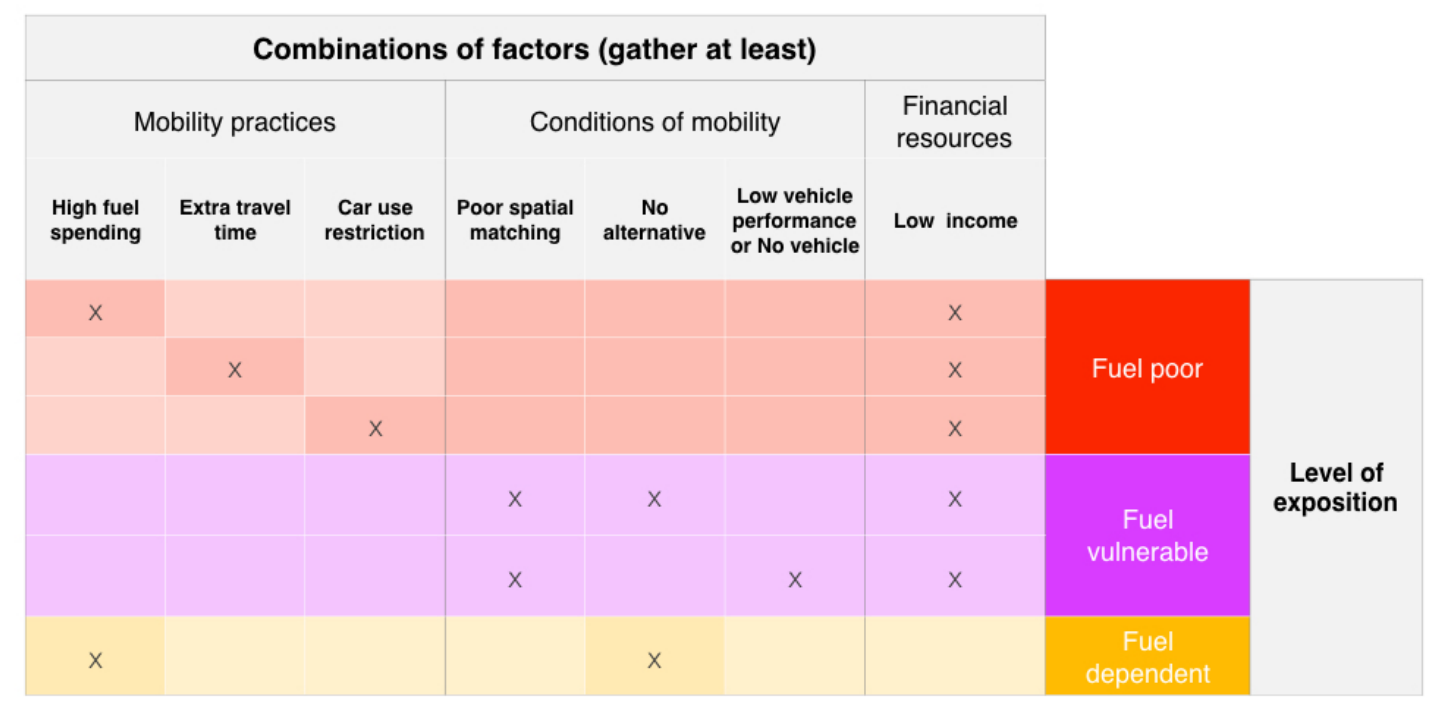

Table 2: Levels of exposition identified with the composite indicator

\section{Application to the French case}

We illustrate our methodology with a case study. This section describes how we operationalize the three indicators proposed in Section 0 in the French context. After presenting the primary data source, we specify the scope of the study, and finally we outline how the different variables required in our analysis are computed. Results are presented and discussed in the next section. 


\subsection{Data source: the National Travel Survey}

Building fuel poverty and vulnerability indicators for the transport sector requires data relative to the socioeconomic characteristics of the households (household structure, economic activity, income...), to the area in which they operate (residential location, location of activities, supply of public transport...) and to their travel behaviours (travelled distances, modes of transport, description of vehicles...). Given these requirements, national travel surveys would usually be prime candidates when looking for potential databases, as it is indeed the case in France.

The National Travel Survey (Enquête Nationale Transports et Déplacements) carried out by the INSEE informs the travel practices of the French population using three elements: a diary filled for one car of the household during a one week period; an interview with one randomly chosen household member (being over 6 years old) about his local travel $(<80 \mathrm{~km})$ the day and the week-end preceding the interview; another interview with one person, again drawn randomly, this time to collect information about his long distance travel $(>80 \mathrm{~km})$ over the three previous months. For each trip indicated by the respondent, the survey database reports the purpose, the trip length and duration, as well as the transportation mode(s). It also provides information regarding access to public transportation and the private means of transport available to the households (including the characteristics of the vehicle(s)). Last, the ENTD provides detailed information on travel related to work and study for all household members over 6 years old.

We use for our application the ENTD 2008 - being the latest edition available - which covers a sample of 20,200 households. Indeed, it especially suits our needs as it provides us with information at the national level on all three required items: household, neighbourhood, travel. ${ }^{10}$

\subsection{Scope of the study}

Fuel poverty in the transport sector focuses on the evaluation of one's travel needs and on the ability to fulfil those needs (see subsection 3.1). Although the ENTD covers all trip purposes, it only does so for one household member. Accordingly, our analysis focuses on commuting (for work or for study), for which information is available for the whole household. All other purposes, including some which one might also deem necessary such as health, basic shopping, or administrative services, fall outside the scope of our analysis. Focusing on commuting trips involves several caveats. This excludes de facto retired and/or unemployed individuals from the analysis, even though these population categories are likely to meet difficulties in fulfilling their travel needs. Because we consider only a part of basic travel needs, car fuel spending is also underestimated. Regarding this second point, the impact on our findings should remain limited, however: commuting trips remain preponderant within required travel, and the fact that we use relative thresholds (based on the median) and not

${ }^{10}$ This led us to discard other possibilities such as using regional travel surveys, because of the scale, or the National Budget Survey, which provides in-depth information on outlays and incomes, but on the other hand very limited information on travel behaviours. 
absolute ones also limits the effect of disregarding other purposes. ${ }^{11}$ Henceforth, 'travel needs' refer to trips related to places of work/study.

\subsection{Computation of the main variables of analysis}

In this subsection, we outline how the main variables required for our analysis are derived. A more thorough description is provided as Supplementary materials (see Appendix).

\section{Distance}

The distance of interest is the sum of the distances travelled by each household member to achieve his travel needs as defined above (commuting for work/study). Motorized distance refers to distances covered by car or by motorcycle, from which we exclude the case of passengers to avoid duplication of fuel spending.

Vehicle performance

Vehicle performance reflects the cost of traveling one kilometre. It conveys information on the fuel efficiency of the vehicle, the fuel type and the horsepower. Moreover, households having no private vehicle are considered at-a-disadvantage in their mobility.

Fuel spending

Fuel spending is derived as the product of the motorized distance and the vehicle fuel efficiency (i.e. the unit cost of per kilometre):

\section{Fuel spending $=$ Motorized distance $*$ Vehicle fuel efficiency}

Income

As our methodology evaluates the household capacity to pay for its travel needs, disposable income appears as the most relevant measure. It is the sum of all earned income (salaries, bonuses), social income (retirement pensions, unemployment benefits, family benefits, housing benefits...) and unearned income, from which several direct taxes (income, housing, and social welfare) are deducted. It represents the total household income available for consumption and savings. The ENTD provides a measure, which is very similar to the disposable income, except that income and housing taxes are not subtracted (while social welfare taxes are). The equivalised disposable income - also used in our analysis - is derived by dividing the income reported in the ENTD by the equivalised household size.

\section{Restriction}

The "Restriction" variable denotes restriction from using one's vehicle on budgetary grounds. More specifically, it characterizes households who have at least one member who chooses not to use the car because it is deemed too expensive. The choice of another transportation mode is not a real choice here, but rather the result of a budget constraint. Restriction is a binary variable.

Alternative

The "Alternative" variable relates to having other options besides the private vehicle to fulfil one's travel needs. It characterizes the availability and accessibility of alternative

\footnotetext{
${ }^{11}$ In 2008 , commuting trips still accounted for $28 \%$ of the total number of trips and $32 \%$ of distances travelled within local travel.
} 
modes of transport in order to reach the place of work/study. A household is identified as having no alternatives if at least one among the members using the car states not having the choice when commuting to one of his places of work/study. The variable "Alternative" is a binary variable.

\section{Extra travel time}

The "Extra travel time" variable is assessed for households who have at least one member using public transport. It is an estimation of the difference in daily travel time between using public transport and using a car for the same commute trip. Distance and travel time by public transport are declared by each individual using public transport. Travel time by car is estimated by multiplying the distance travelled by public transport by an average speed differentiated by residential location. Extra travel time can be positive or negative depending on whether traveling by public transport is longer or shorter respectively.

\section{Extra travel time $=$ Travel time by public transport - Distance $*$ Speed $[$ location $]$}

\section{Results and discussion}

\subsection{Ratio indicator}

Ratio indicator identifies households spending a high share of their income on buying fuel. 10,5\% (2,6 millions) of French households are identified by the ratio indicator. The threshold being set at twice the median ratio, fuel poor households spend more than $3.9 \%$ of their income on fuel for their daily commute. Because it mainly concerns commute to workplaces, this spending is unavoidable and can be interpreted as a decrease in the household net income. If costs and maintenance costs of cars are added, the residual income is all the more impacted, which weakens the situation of households with limited incomes, thus amplifying their poverty.

Figure 2 represents fuel spending as a function of income for the household sample, and the ratio indicator threshold (in purple line). We find that the ratio indicator applied to the transport sector suffers from the same limitation as in the domestic sector: it is not selective with respect to income, capturing households from all income classes. To overcome this drawback, a solution is to add a criterion relative to income: to be considered fuel poor, a household must be income poor ${ }^{12}$. According to INSEE, income poor were households earning less than $950 €$ per CU (consumption unit) in 2008 in France. The ratio indicator restricted to income poor households identifies 2,0\% (510 000) households as fuel poor. The substantial variation in the extent of identified households - from $10,5 \%$ to $2,0 \%$ - confirms that a large share of fuel poor households according to the ratio indicator actually have modest to higher standards of living.

To conclude, the ratio indicator measures the weight of commuting-related fuel spending in the household budget. It is based on the premise that spending more than a certain share of income is problematic. The relevance of this indicator is directly related to whether households above the fixed threshold experience a disproportionate pressure on their budget. The value of the threshold, twice the median income, is quite low $(3,9 \%)$. It will

\footnotetext{
${ }^{12} \mathrm{~A}$ household is considered to be income poor if its income falls below the poverty threshold, with is usually set at $60 \%$ of the median.
} 
represent a pressure mainly for low-income households, hence our choice to restrict the ratio indicator to income poor households.

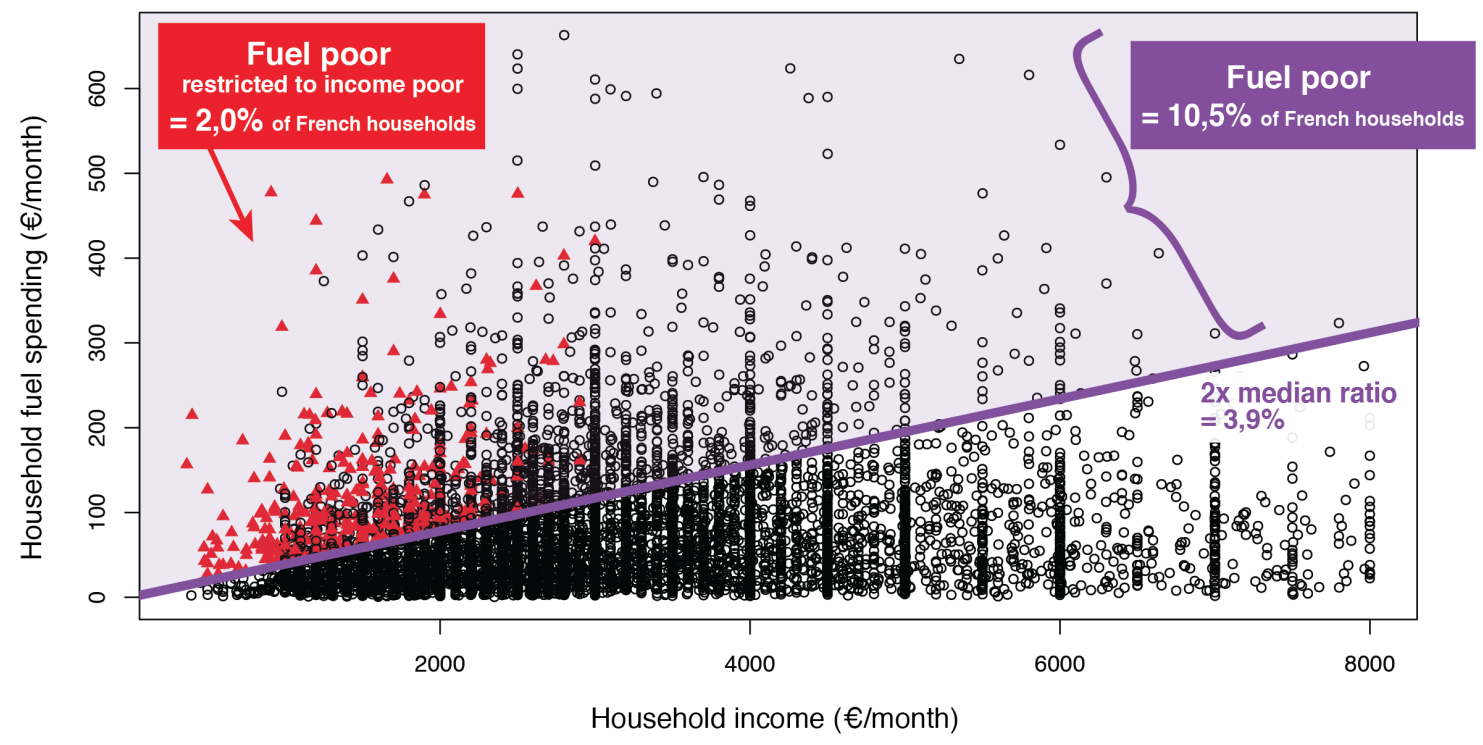

Note: each dot represents one household from the survey data. The purple line corresponds to twice the median income share for fuel spending. Red triangles correspond to households identified by the ratio indicator restricted to income poor households.

Source: ENTD 2008

Figure 2: Households identified as fuel poor by the ratio indicator

\subsection{4. $\quad$ LIHC indicator}

According to the LIHC indicator, 3,3\% (840 000 households) French households are identified fuel poor in their travel needs. LIHC is composed of two dimensions: fuel spending per active ${ }^{13}$ person, and residual income after fuel spending per consumption unit. Fuel spending per person reflects the mean "fuel cost of access to employment" for the household. It is compared with a threshold equal to the median spending, $32 € /$ month. Residual income is compared with a threshold equals to the poverty line which was valued at $950 € / C U / m o n t h$ in France in 2008 according to INSEE.

The overlap between LIHC and ratio indicators is only partial (see table 3 and figure 3). Only $52 \%$ of the households identified fuel poor with LIHC are identified fuel poor with ratio indicator restricted to income poor. Two differences explain this gap. The first comes from the number of active persons per households and the level of income per active person. The ratio indicator considers the fuel spending in relation to total household income. It tends to identify households with a low level of income per active person and/or a low number of active persons, both leading to a low total income. It accounts for the capacity to afford commuting and reflects the fuel efficiency of earning one euro. The LIHC indicator considers

${ }^{13}$ In France, active people relates to the working-age people that are available on the labor market, they can have a job (working population) or be unemployed (non-working active population). 
fuel spending per active person. It tends to identify households with few active persons, independently of their level of income. It accounts for the fuel footprint of commuting and reflects the fuel efficiency of having a source of income. The second difference comes from the method used to define income poor. In the ratio indicator restricted to income poor, they are defined as households with income per CU lower than the poverty line. In the LIHC indicator, income poor households are those with residual income per $\mathrm{CU}$ after excluding fuel cost lower than the poverty line. Thus LIHC retains more households: in addition to households retained by the ratio definition, it includes households whose standard of living is lowered because of their fuel spending.

Table 3: Overlap between households identified fuel poor with Ratio/IP and/or LIHC (\%), ENTD 2008

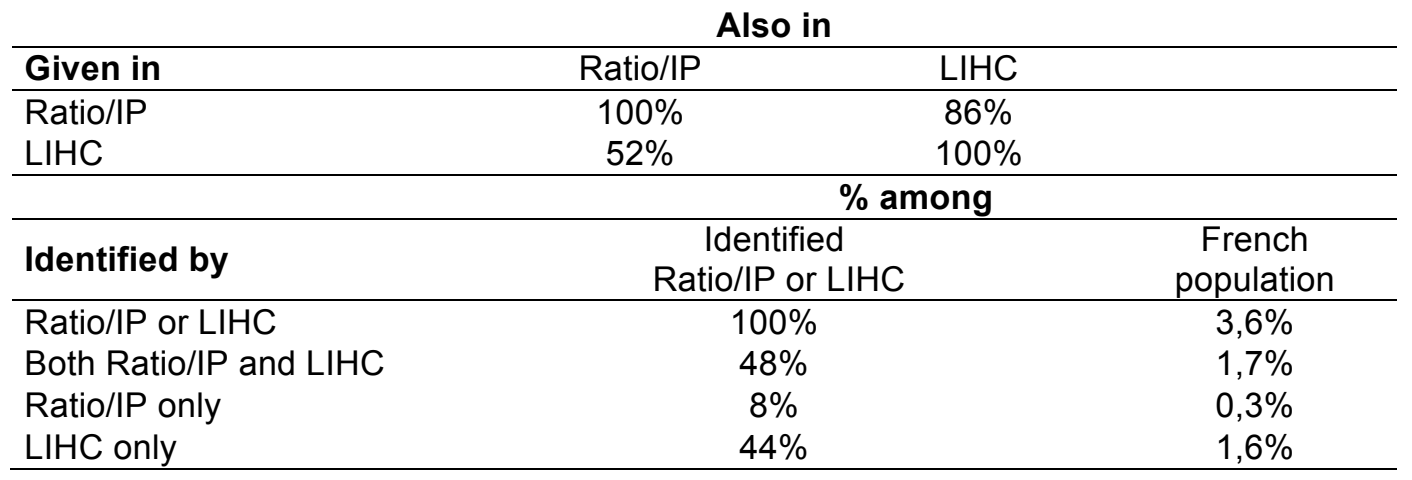




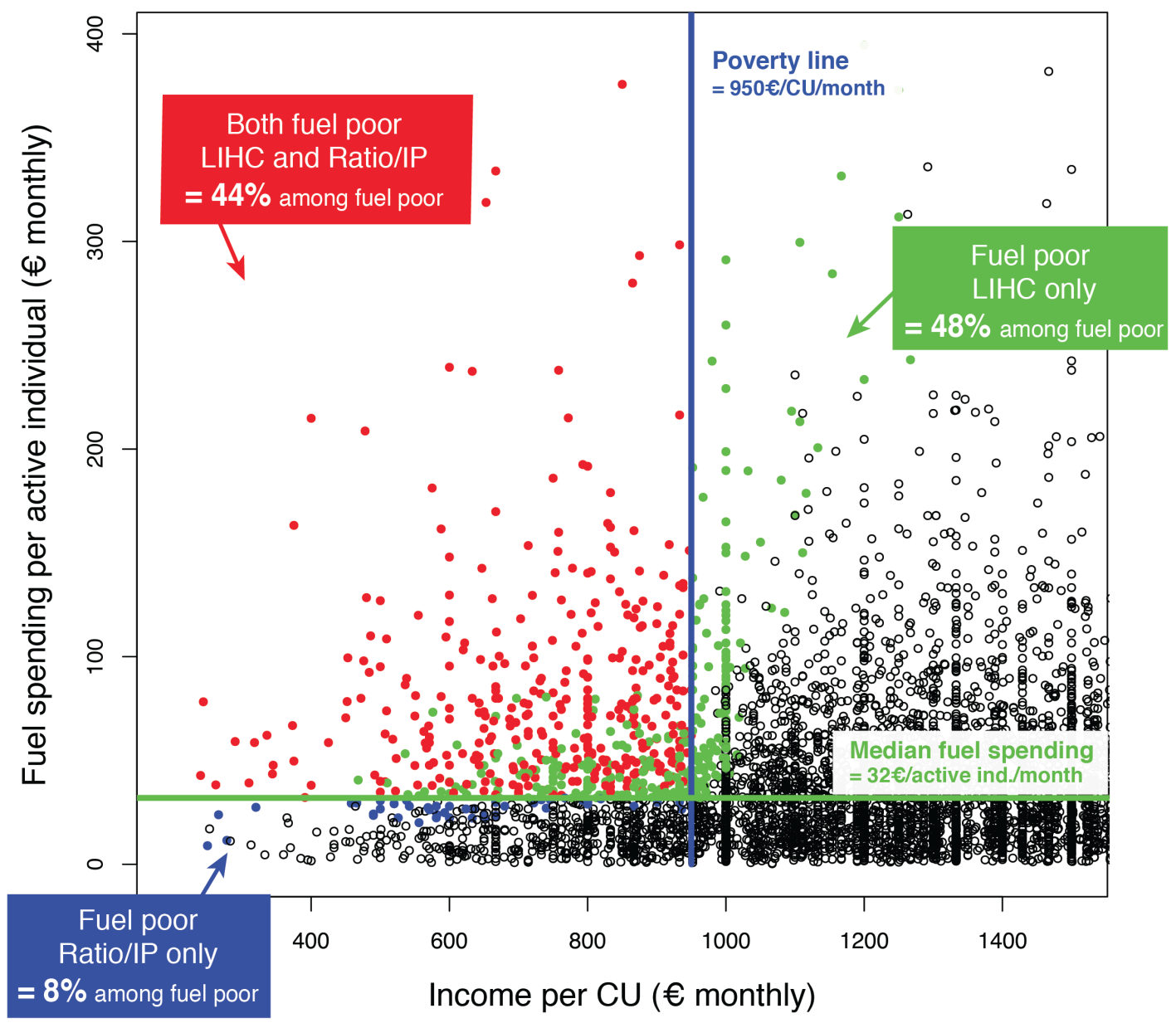

Note: each dot represents one household from the survey data. The blue and green lines depict the poverty line and the median fuel spending, respectively. Red dots correspond to households identified by both the ratio indicator restricted to income poor (Ratio/IP) households and the LIHC indicator. Green dots correspond to households identified by the LIHC indicator but not by the Ratio/IP indicator, and vice versa for blue dots.

Figure 3: Comparison of households identified as fuel poor by the LIHC and ratio indicators

The LIHC indicator identifies households combining a low residual income per CU and a high fuel cost per active person. It is relevant if a given amount of fuel spending per active person can be defined as a threshold above which situations are problematic. Following LIHC used in the domestic sector, this threshold is defined as the median spending. It gives a normative approach to (motorised) private transportation. Still following LIHC for domestic energy, the threshold would be interpreted as a standard for efficiency in one's mobility. However travel needs are diverse (see subsection 3.2) which questions the relevance of this normative approach.

Furthermore, using the residual income after fuel costs, that is to say after excluding fuel costs from the disposable income, has advantages and drawbacks. It has the advantage to account for households whose standard of living is lowered because of their motorised travels. It is derived from the Minimum Income Standard approach, which consists in defining a minimum income needed by a household to participate in society. Here households are 
considered at a disadvantage - in LI dimension of LIHC - if, after deducting their actual fuel costs, they have insufficient residual income to meet all their other minimum living costs. It acknowledges fuel spending cannot only exacerbate income poor situation but can also induce new poverties. However introducing the fuel spending in the LI dimension also has drawbacks: first it adds complexity in the understanding and interpretation of the LI dimension (residual income AFTER fuel cost is compared with a threshold based on the income BEFORE fuel cost), second it is redundant as the fuel spending is already assessed in the $\mathrm{HC}$ dimension and would not allow to separate the effect of a change in fuel prices from the effect of a change in income levels in the evaluation of fuel poverty.

To conclude, LIHC indicator identifies households having both a high fuel spending per active person and a low residual income after fuel costs. High fuel spending is taken as higher than the median value, which is arbitrarily defined as a standard, and this introduction of a normative approach to individual travel needs does not appear consistent with the diversity in travel needs. Low income identifies households having a low residual income after fuel costs, which is more comprehensive in seizing the difficulties caused by one's fuel spending but introduces redundancy - double evaluation of the fuel dimension - and confusion - in the understanding of LIHC. We find this direct transposition of LIHC is not satisfactory to assess fuel poverty in the transport sector.

Ratio and LIHC indicators respectively measure the impact of the fuel cost on the household budget and the fuel cost of access to employment. However, they do not identify households who restrict their use of car, although it is an acute expression of deprivation. They do not consider either households that show disadvantageous conditions of mobility (poor spatial matching, no alternative, low vehicle performance or no vehicle), which limits households ability to adapt to fuel prices rise. Thus we find the simple transposition of existing fuel poverty indicators to the transport sector is unsatisfactory. The composite indicator we propose below considers the different dimensions of fuel poverty in the transport sector.

\subsection{Composite indicator}

The composite indicator identifies disadvantageous combinations of factors reflecting an exposition to fuel prices rise. More specifically it identifies three levels of exposition to an increase in fuel prices: fuel poverty, fuel vulnerability and fuel dependency. The combinations of factors corresponding to each level of exposition are described in section 4 and summarized in Table 4. 


\begin{tabular}{|c|c|c|c|c|c|}
\hline & Factor & $\begin{array}{l}\text { Threshold } \\
\text { (Exposed if) }\end{array}$ & $\begin{array}{l}\text { Number of } \\
\text { households }\end{array}$ & $\begin{array}{l}\text { Share among } \\
\text { households } \\
\text { with required } \\
\text { mobility }\end{array}$ & $\begin{array}{c}\text { Share among } \\
\text { French } \\
\text { households }\end{array}$ \\
\hline \multirow{3}{*}{$\begin{array}{l}\text { Mobility } \\
\text { practices }\end{array}$} & $\begin{array}{l}\text { High fuel } \\
\text { spending }\end{array}$ & $\begin{array}{l}>64 \\
€ / \text { active/month } \\
\text { (2x median) }\end{array}$ & 2500000 & $15,3 \%$ & $9,8 \%$ \\
\hline & Extra travel time & $\begin{array}{l}\text { At least one } \\
\text { person with }>60 \\
\text { extra min/day } \\
\text { when using public } \\
\text { transport compared to } \\
\text { using car }\end{array}$ & 300000 & $1,9 \%$ & $1,2 \%$ \\
\hline & Car use restriction & 1 & 1300000 & $8,1 \%$ & $5,2 \%$ \\
\hline \multirow{3}{*}{$\begin{array}{l}\text { Conditions of } \\
\text { mobility }\end{array}$} & $\begin{array}{l}\text { Poor spatial } \\
\text { matching }\end{array}$ & $\begin{array}{l}>382 \\
\mathrm{~km} / \text { active/month } \\
\text { (median) }\end{array}$ & 8000000 & $50,1 \%$ & $32,0 \%$ \\
\hline & No alternative & 1 & 7200000 & $44,8 \%$ & $28,7 \%$ \\
\hline & $\begin{array}{l}\text { Low vehicle } \\
\text { performance } \\
\text { or No vehicle }\end{array}$ & $\begin{array}{l}>10 \mathrm{c} € / \mathrm{km} \\
\text { or } 0 \text { vehicle }\end{array}$ & 300000 & $15,9 \%$ & $10,2 \%$ \\
\hline $\begin{array}{l}\text { Financial } \\
\text { resources }\end{array}$ & Low income & $\begin{array}{l}<1580 \\
\text { €/UC/month } \\
\text { (median) }\end{array}$ & 9300000 & $57,7 \%$ & $36,9 \%$ \\
\hline \multirow{3}{*}{$\begin{array}{l}\text { Composite } \\
\text { indicator }\end{array}$} & \multicolumn{2}{|l|}{ Fuel poor } & 1900000 & $12,1 \%$ & $7,8 \%$ \\
\hline & \multicolumn{2}{|l|}{$\begin{array}{l}\text { Fuel vulnerable } \\
\text { (out of fuel poor) }\end{array}$} & 3000000 & $\begin{array}{l}18,7 \% \\
(11,5 \%)\end{array}$ & $\begin{array}{c}12,0 \% \\
(7,4 \%)\end{array}$ \\
\hline & \multicolumn{2}{|c|}{$\begin{array}{l}\text { Fuel dependent } \\
\text { (out of fuel poor \& fuel vulnerable) }\end{array}$} & 1900000 & $\begin{array}{l}11,7 \% \\
(5,8 \%)\end{array}$ & $\begin{array}{c}7,5 \% \\
(3,7 \%)\end{array}$ \\
\hline $\begin{array}{c}\text { LIHC } \\
\text { indicator }\end{array}$ & \multicolumn{2}{|l|}{ Fuel poor } & 840000 & $5,2 \%$ & $3,3 \%$ \\
\hline \multirow{2}{*}{$\begin{array}{c}\text { Ratio } \\
\text { indicator }\end{array}$} & \multicolumn{2}{|l|}{ Fuel poor } & 2620000 & $16,3 \%$ & $10,5 \%$ \\
\hline & \multicolumn{2}{|c|}{ Fuel poor (restricted to income poor) } & 510000 & $3,2 \%$ & $2,0 \%$ \\
\hline
\end{tabular}

Table 4: Results per factor and per indicator

2.

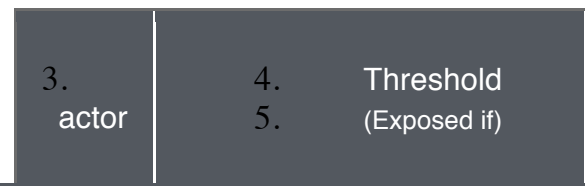

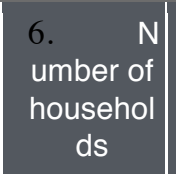

N) 7.

hare among households with required mobility hare

among

French 


\begin{tabular}{|c|c|c|c|c|c|c|}
\hline & & & & & & $\begin{array}{l}\text { househ } \\
\text { olds }\end{array}$ \\
\hline \multirow{3}{*}{$\begin{array}{l}\text { 9. Eff } \\
\text { ective } \\
\text { mobility }\end{array}$} & $\begin{array}{l}10 . \\
\text { igh fuel } \\
\text { spendi } \\
\text { ng }\end{array}$ & $>64$ €/active/month & $\begin{array}{r}12 . \\
500000^{2}\end{array}$ & 13. & $15,3 \%$ & $\underset{, 8 \%}{14 .} 9$ \\
\hline & $\begin{array}{l}15 . \\
\text { xtra } \\
\text { travel } \\
\text { time }\end{array}$ & $\begin{array}{l}\text { 16. }>60 \text { min/active/day } \\
17 . \\
\text { hen using public transport } \\
\text { compared to using car }\end{array}$ & $18.00000^{3}$ & 19. & $1,9 \%$ & $\underset{, 2 \%}{20 .}$ \\
\hline & $\begin{array}{l}21 . \\
\text { ar use } \\
\text { restricti } \\
\text { on }\end{array}$ & 22. & $\begin{array}{r}23 . \\
300000\end{array}$ & 24. & $8,1 \%$ & $\underset{, 2 \%}{25 .} 5$ \\
\hline \multirow{3}{*}{$\begin{array}{c}\text { 26. Co } \\
\text { nditions of } \\
\text { mobility }\end{array}$} & $\begin{array}{l}27 . \\
\text { oor } \\
\text { spatial } \\
\text { matchi } \\
\text { ng }\end{array}$ & $\begin{array}{l}28 . \quad>382 \\
\mathrm{~km} / \text { active/month }\end{array}$ & $\begin{array}{c}29 . \\
000000\end{array}$ & 30. & $50,1 \%$ & ${ }_{2,0}^{31 .}{ }^{3}$ \\
\hline & $\begin{array}{l}32 . \\
\text { O } \\
\text { alternat } \\
\text { ive }\end{array}$ & 33. & $\begin{array}{r}34 . \\
200000\end{array}$ & 35. & $44,8 \%$ & $36.7 \%$ \\
\hline & $\begin{array}{l}37 . \\
\text { ow } \\
\text { vehicle } \\
\text { perfor } \\
\text { mance } \\
38 \text {. } \\
\text { r No } \\
\text { vehicle }\end{array}$ & $\begin{array}{l}>10 \mathrm{c} € / \mathrm{km} \\
\text { or } 0 \text { vehicle }\end{array}$ & $41.00000^{3}$ & 42. & $15,9 \%$ & $\underset{0,2 \%}{43 .}$ \\
\hline $\begin{array}{l}\text { 44. Fin } \\
\text { ancial } \\
\text { resources }\end{array}$ & $\begin{array}{l}45 . \\
\text { ow } \\
\text { income }\end{array}$ & $<1580 € /$ UC/month & $\begin{array}{l}47 . \\
300000\end{array}$ & 48. & $57,7 \%$ & ${ }_{6,9}^{49}{ }^{3}$ \\
\hline \multirow{3}{*}{$\begin{array}{l}50 . \quad \mathrm{C} \\
\text { omposit } \\
\text { e } \\
\text { indicator }\end{array}$} & 51. & Fuel poor & $\begin{array}{lr}52 . & 1 \\
900 & 000\end{array}$ & 53. & $12,1 \%$ & $\begin{array}{c}54 . \\
, 8 \%\end{array}$ \\
\hline & $\begin{array}{l}55 . \\
56 .\end{array}$ & $\begin{array}{l}\text { Fuel vulnerable } \\
\text { (out of fuel poor) }\end{array}$ & $\begin{array}{rr}57 . & 3 \\
000000\end{array}$ & $\begin{array}{r}58 . \\
59 .\end{array}$ & $\begin{array}{c}18,7 \% \\
(11,5 \%)\end{array}$ & $\begin{array}{l}60 . \\
2,0 \% \\
61 . \\
7,4 \%)\end{array}$ \\
\hline & $\begin{array}{l}62 . \\
63 . \\
\text { out of fuel }\end{array}$ & $\begin{array}{l}\text { Fuel dependent } \\
\text { | poor \& fuel vulnerable) }\end{array}$ & $\begin{array}{rr}64 . & 5 \\
000 & 000\end{array}$ & $\begin{array}{c}65 . \\
66 .\end{array}$ & $\begin{array}{c}31,7 \% \\
(13,9 \%)\end{array}$ & $\begin{array}{c}67 . \\
0,3 \% \\
68 . \\
8,9 \%)\end{array}$ \\
\hline $\begin{array}{l}69 . \quad \text { LI } \\
\text { indicator }\end{array}$ & 70. & Fuel poor & $41.000^{8}$ & 72. & $5,2 \%$ & ${ }_{, 3}^{73 .}{ }^{3}$ \\
\hline \multirow{2}{*}{$\begin{array}{l}\text { 74. } \mathbf{R} \\
\text { atio } \\
\text { indicator }\end{array}$} & 75. & Fuel poor & $\begin{array}{rr}76 . & 2 \\
620 & 000\end{array}$ & 77. & $16,3 \%$ & $\begin{array}{ll}78 . & 1 \\
0,5 & 1\end{array}$ \\
\hline & 79. & & $\frac{80 .}{10} 000^{5}$ & 81. & $3,2 \%$ & $\begin{array}{l}82 . \\
, 0 \%\end{array}$ \\
\hline
\end{tabular}


Fuel poor are households living below the median standard of living $(<1580 € / C U / m o n t h)$ with high fuel spending ( $>64 € /$ month/active person) or extra travel time or declaring car use restriction. 7.8\% (1.9 million) of French households are identified fuel poor. This is a modified version of LIHC. The income dimension refers to households' income (instead of the residual income after excluding fuel costs) and compares it to the median standard of living. It has the advantage to separate out the income dimension of fuel poverty. As for LIHC, high cost refers to the fuel spending per active person, but the threshold is defined as twice the median spending, instead of the median spending. It retains households who have the highest spending. This assessment of fuel poverty is enlarged to account for other difficulties that may show itself in face of too high fuel prices, that is to say households disadvantaged by much longer travel times when using public transport compared to using car as well as households declaring restriction in their vehicle usage. According to ENTD $2008,8,1 \%$ of households with travel needs state they "do not use the car regularly because it is too expensive" 14 .

Table 5: Overlap between households identified fuel poor with Composite, Ratio/IP and LIHC (\%), ENTD 2008

\begin{tabular}{lccc}
\multicolumn{3}{c}{ Also in } \\
\hline Given in & Ratio/IP & LIHC & $\begin{array}{c}\text { Composite } \\
\text { Fuel poor }\end{array}$ \\
\hline Ratio/IP & - & $86 \%$ & $58 \%$ \\
LIHC & $52 \%$ & - & $53 \%$ \\
Composite Fuel poor & $15 \%$ & $23 \%$ & -
\end{tabular}

The composite indicator has only partial overlap with LIHC and ratio indicators (Table 5). Only $53 \%$ of households identified as fuel poor by LIHC are also identified as fuel poor by the composite indicator. However we noted that LIHC may overestimate the issue, due to the low value of the fuel spending threshold. Conversely only $23 \%$ of households identified with composite indicator are also identified with LIHC. The difference comes from the changes we proposed in the thresholds as well as from the account for extra travel time and car use restriction behaviours. In terms of the income dimension, composite is enlarged to households living under the median standard of living, ant not the poverty line. Using the poverty line would have excluded those households whose standard of living falls below the poverty line because of their fuel spending that are identified with LIHC. In terms of fuel spending, composite detects households spending more than twice the median spending per person rather than more than the median spending. This is to account for the variety of travel needs and restrict the analysis to the highest fuel spending. For spending located between the median and twice the median, it is difficult to judge whether they reveal actual difficulties

${ }^{14}$ This question related to restriction was subject to a high non-response rate (84\%). We find $50 \%$ of households who actually answered the question state they "do not use the car regularly because it is too expensive". 
for households or if they result from households preferences. Finally, the composite indicator accounts for households declaring restricting their usage of car and those suffering from a daily one hour extra travel time because of inadequate public transport (compared to using the car). Households who do not show a high spending, but suffer from extra travel time or declare restriction are identified by the composite indicator whereas they are not identified with LIHC. $36 \%$ of the households identified fuel poor by the composite indicator declare restriction, and $11 \%$ have a member suffering from at least one hour extra travel time. This result highlights the importance of assessing restriction and extra travel time for evaluating fuel poverty in the transport sector. More importantly, it raises concerns in face of rising fuel prices; an increasing number of households could be forced to adjust their travel behaviours by reducing their usage of car even if it implies shifting to inadequate public transport. If this is good news for energy saving and climate objectives, this should be accompanied by measures to provide suitable, accessible and affordable alternatives to car.

Fuel vulnerable are characterized by a low income $(<1580 € / \mathrm{CU} / \mathrm{month})$ and the combination of disadvantageous conditions of mobility (poor spatial matching, no alternative, poor vehicle performance or no vehicle). These constraints limit their capacity to adapt to a change in their situation. $12.0 \%$ (3,0 millions) of French households are identified fuel vulnerable. The limits of their present situation can give rise to future difficulties, especially in case of an unexpected change of situation (new-born baby, change workplace, higher housing costs, etc.).

Fuel dependents are households combining a high fuel spending ( $>64 € /$ month/active person) with no alternative mode of transport. In case of fuel prices rise, their fuel spending could highly increase and result in financial stress. 7,5 \% (1,9 millions) of French households are identified fuel dependents. These households have limited leeway to adapt, so that households with high committed spending such as loan reimbursement or payment of children studies could be negatively affected in their monthly budget,in case of a sharp increase in fuel prices.

Figure 4 shows households according to their highest level of exposition: fuel poor > fuel vulnerable > fuel dependent. Two thresholds are drawn: the green line equals twice the median fuel spending per active person, which is estimated at $64 € /$ month; the blue line corresponds to the median income per CU which was $1580 € / C U / m o n t h$ in France in 2008.

Fuel poor represent $7,8 \%$ of French households, while fuel vulnerable (excluding fuel poor) are $7,4 \%$ and fuel dependents (excluding fuel vulnerable and fuel poor) are $3,7 \%$. If being fuel poor is about enduring difficulties in one's mobility practices, we see conditions of mobility weaken other parts of the population that are not identified by an indicator solely based on budgetary factors. Our results show fuel poverty in the transport sector points out to issues of distributive injustice in access to mobility due to the interaction between underlying inequalities related to income, motorisation, energy efficiency, public transport system, or location. Overall $18,8 \%$ of French population is exposed to rising fuel prices. It represents 4,7 million households, among which $59 \%$ are identified because of disadvantageous conditions of mobility and $33 \%$ are identified because of other impacts than the fuel spending (extra travel time and car use restriction). Only the remaining $8 \%$ are identified because their high fuel spending, even though $45 \%$ of exposed households show a high fuel spending. 


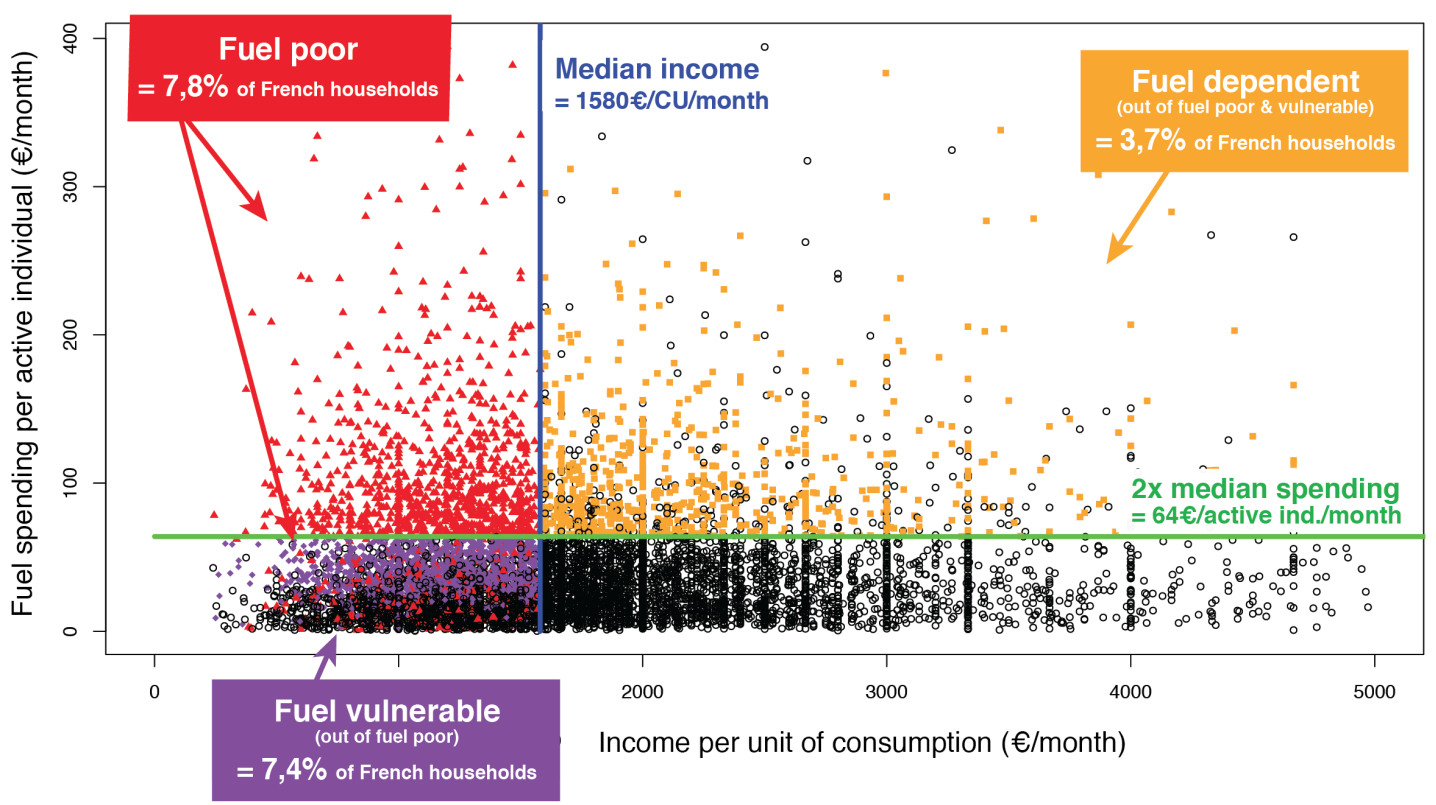

Scope: households with at least one member commuting by car

Note: each dot represents one household from the survey data. The blue and green lines depict the median income and two times the median fuel spending, respectively. Red / purple / yellow dots correspond to households identified fuel poor / fuel vulnerable / fuel dependent respectively.

Source: ENTD 2008

Figure 4: Classification of households according to the three levels of exposition

\section{Conclusion}

This article proposes new indicators to quantify fuel poverty in the transport sector. First, we have tried to transpose the fuel poverty indicators from the domestic sector, namely the Ratio and LIHC indicators, to the transport sector. We have shown that because they focus on budget aspects, they do not account for the whole range of factors at stake with fuel poverty in the transport sector. They fail to reflect the (in)adequacy of the conditions of mobility and the (in)ability households have to adapt in face of rising fuel prices, which are both at the heart of fuel poverty in the transport sector.

To overcome the limits of existing indicators, we have built a composite indicator combining an assessment of financial resources, mobility practices and households' conditions of mobility. Derived from multidimensional poverty measurement, this indicator consists of several factors, which can be economic, technical, geographic or cross dimensional. It considers: (1) diverse travel needs, (2) restriction behaviours, (3) variable household adaptive capacities. Our composite indicator reflects multiple combinations of factors translating exposition to rising fuel prices into a single indicator. Furthermore, it differentiates three levels of exposition to rising fuel prices.

The application on French data has shown that the households identified by the composite indicator differ from those identified by the ratio or the LIHC indicators, with only partial overlaps. Risks of false inclusion or exclusion are therefore important if inadequate indicators are used. Consequently, it appears that the composite indicator has the potential to offer more precise quantification of fuel poverty in the transport sector, and to serve as a 
basis for policy targeting and evaluation. Considering data requirements, implementing the composite indicator would usually call for the use of national or regional transport surveys. These would usually include all the data needed, except for possibly two elements: the presence of alternatives, and the restriction phenomenon. The first point could be inferred by comparing the household location to the transport supply. The second point would call for either a new dedicated question or alternatively for an econometric analysis to detect the cases of under-consumption of transport.

Our findings are subject to a certain number of caveats. Travel needs are restricted to commuting trips. While other activities are likely essential to the household well-being (such as health, shopping, or visit to family and friends) besides work and study, limitations of available data in the French National Transport Survey prevented us from doing so. Including these other trip purposes would surely enrich the analysis, but would also involve further work in order to be able to discriminate between required and discretionary travel. Among the main limitations of restricting the scope to commuting trips, let us first note that the case of retired or unemployed individuals is de facto not treated in our analysis. Car fuel spending is also underestimated compared to a situation where we would include other travel needs. This point is mitigated by the fact that we consider relative and not absolute thresholds when analysing the level of fuel spending, however. Finally, fuel spending typically represents only 30 to $40 \%$ of total car spending in most countries, so that another risk for low-income car dependent households lies in the risk of being unable to pay for a major repair, or to afford parking costs for example. Again, the choice of relative thresholds partly remedies this limitation of the study.

Further research includes (i) testing the composite indicator on other data representing different situations, on finely territorialised data to refine situations of vulnerability, or on panel data to study dynamic evolutions; (ii) identifying the characteristics of households identified in the three levels of exposition to rising fuel prices; (iii) coupling the analysis with the domestic sector, as well as with other sources of vulnerability (insecure employment, mortgages, single parents...); (iv) develop a full vulnerability assessment, with a more comprehensive consideration of adaptive capacity, in a conceptual framework to be adapted; (v) simulate the effect of fuel price rising and/or policies. A microsimulation study could allow testing various hypotheses on the evolutions of the system as a whole, such as modelling the opportunity for households to replace their car with recent efficient cars, to shift to other modes of transport or to relocate closer to one's workplace, as well as the impact of the rise of fuel prices on households' disposable income.

\section{Bibliography}

Adger, W. N. (2006). Vulnerability. Global Environmental Change, 16(3), 268-281.

Aguilera, A., \& Mignot, D. (2003). Etalement urbain et mobilité. Revue d'économie régionale et urbaine: RERU, (5), pp. 815-834.

Alkire, S., \& Foster, J. (2011). Understandings and misunderstandings of multidimensional poverty measurement. Journal of Economic Inequality, 9(2), 289-314.

Alterre Bourgogne. (2007). Cartographies de la vulnérabilité énergétique des ménages bourguignons. Retrieved from http://www.alterrebourgogne.org/arkotheque/client/alterre_bourgogne/_depot_arko/basesdoc/4/2117/rt- 
cartographie-vulnerabilite-energetique.pdf

Beaufils, S., Bouleau, M., Davy, A.-C., Mangeney, C., \& Mettetal, L. (2014). La vulnérabilité énergétique des ménages franciliens. IAU IDF. Retrieved from http://www.iau-idf.fr/savoirfaire/nos-travaux/edition/la-vulnerabilite-energetique-des-menages-franciliens.html

Berri, A. (2007). Transport consumption inequalities and redistributive effects of taxes. In World Conference on Transport Research, Berkeley. Retrieved from http://www.wctrs.leeds.ac.uk/wp/wpcontent/uploads/abstracts/berkeley/G4/954/Berri_WCTR2007_G4_transp-cons-ineq_v2.doc

Boardman, B. (1991). Fuel poverty: from cold homes to affordable warmth. Retrieved from http://www.getcited.org/pub/102876409

Bohle, H. G., Downing, T. E., \& Watts, M. J. (1994). Climate change and social vulnerability: Toward a sociology and geography of food insecurity. Global Environmental Change, 4(1), 37-48. http://doi.org/10.1016/0959-3780(94)90020-5

Bouzarovski, S., \& Petrova, S. (2015). A global perspective on domestic energy deprivation: Overcoming the energy poverty-fuel poverty binary. Energy Research \& Social Science, 10, 31-40. http://doi.org/10.1016/j.erss.2015.06.007

Bradshaw, J., \& Hutton, S. (1983). Social policy options and fuel poverty. Journal of Economic Psychology, 3(3-4), 249-266. http://doi.org/10.1016/0167-4870(83)90005-3

Büttner, B., Franz, S., Reutter, U., \& Wulfhorst, G. (2012). MORECO-Mobility and Residential Costs: Improving the Settlement Development in the Transnational Alpine Space Region. na. Retrieved from http://www.researchgate.net/profile/Peter_Zeile/publication/267382989_(Print)_Editors_MORCO _Mobility_and_Residential_Costs_Improving_the_Settlement_Development_in_the_Transnation al_Alpine_Space_Region/links/5461e56b0cf27487b4535810.pdf

Chancel, L., Erard, T., \& Saujot, M. (2015). Quelle stratégie de lutte contre la précarité énergétique? Propositions pour une politique de transition écologique et sociale. POLICY BRIEFS N02/2015. IDDRI, 4 P. Retrieved from http://www.iddri.org/Publications/Reussir-latransition-socialecologique-pour-une-strategie-de-lutte-contre-la-precarite-energetique

Cochez, N., Durieux, E., \& Levy, D. (2015, January). Vulnérabilité énergétique Loin des pôles urbains, chauffage et carburant pèsent fortement dans le budget. INSEE. Retrieved from http://www.insee.fr/fr/ffc/ipweb/ip1530/ip1530.pdf

Coulombel, N., \& Leurent, F. (2013). Les ménages arbitrent-ils entre coût du logement et coût du transport: une réponse dans le cas francilien. Economie et Statistique, 457-458, 57-75.

DETR. (2000). DETR (Department of the Environment, Transport and the Regions), 2000. English House Condition Survey 1996: Energy Report. DETR, London, pp. 119-144.

Dodson, J., \& Sipe, N. (2007). Oil vulnerability in the Australian city: Assessing socioeconomic risks from higher urban fuel prices. Urban Studies, 44(1), 37-62.

Dubois, U., \& Meier, H. (2014). Households Facing Constraints. Fuel Poverty Put into Context (EWI Working Paper No. 2014-7). Energiewirtschaftliches Institut an der Universitaet zu Koeln. Retrieved from http://ideas.repec.org/p/ris/ewikln/2014_007.html

Fruchart, A. (2012). La précarité énergétique en Seine Aval, Note de l'Observatoire Seine Aval. Retrieved from http://www.audas.fr/joomla1.5/images/stories/pdf/Notes/OSA/Precar_enrg.pdf

Gaschet, F., \& Gaussier, N. (2005). Chapitre 12. Les échelles du mauvais appariement spatial au sein de l'agglomération bordelaise. In M.-A. Buisson \& D. Mignot, Concentration économique et ségrégation spatiale (p. 221). De Boeck Supérieur. Retrieved from 
http://www.cairn.info/concentration-economique-et-segregation-spatiale--9782804148775page-221.htm

Guyet, R. (2014). La précarité énergétique en Europe: approche comparative. La Documentation française. Retrieved from http://www.ladocumentationfrancaise.fr/pageseurope/d000733-la-precarite-energetique-en-europe-approche-comparative-par-rachelguyet/article

Heindl, P., \& Löschel, A. (2015). Social implications of green growth policies from the perspective of energy sector reform and its impact on households (ZEW Discussion Paper No. 15-012). ZEW - Zentrum für Europäische Wirtschaftsforschung / Center for European Economic Research. Retrieved from https://ideas.repec.org/p/zbw/zewdip/15012.html

Hills, J. (2012a). Getting the measure of fuel poverty: final report of the Fuel Poverty Review [Monograph]. Retrieved April 22, 2014, from http://sticerd.Ise.ac.uk/case/

Hills, J. (2012b). Getting the measure of fuel poverty: final report of the Fuel Poverty Review [Monograph]. Retrieved April 22, 2014, from http://sticerd.Ise.ac.uk/case/

Huyghe, M., Baptiste, H., \& Carrière, J.-P. (2013). Quelles organisations de la mobilité plus durables et moins dépendantes de la voiture dans les espaces ruraux à faible densité ? L'exemple du Parc naturel régional Loire-Anjou-Touraine. Développement durable et territoires. Économie, géographie, politique, droit, sociologie, (Vol. 4, $\mathrm{n}^{\circ} 3$ ). http://doi.org/10.4000/developpementdurable.10000

IPCC, 2014: Climate Change 2014: Impacts, Adaptation, and Vulnerability. Summaries, Frequently Asked Questions, and Cross-Chapter Boxes. A Contribution of Working Group II to the Fifth Assessment Report of the Intergovernmental Panel on Climate Change [Field, C.B., V.R. Barros, D.J. Dokken, K.J. Mach, M.D. Mastrandrea, T.E. Bilir, M. Chatterjee, K.L. Ebi, Y.O. Estrada, R.C. Genova, B. Girma, E.S. Kissel, A.N. Levy, S. MacCracken,P.R. Mastrandrea, and L.L. White (eds.)]. World Meteorological Organization, Geneva, Switzerland, 190 pp.

Jones, P., \& Lucas, K. (2012). The social consequences of transport decision-making: clarifying concepts, synthesising knowledge and assessing implications. Journal of Transport Geography, 21, 4-16. http://doi.org/10.1016/j.jtrangeo.2012.01.012

Jouffe, Y., \& Massot, M.-H. (2013). Vulnérabilités sociales dans la transition énergétique au croisement de l'habitat et de la mobilité quotidienne. In 1er Congrès interdisciplinaire du Développement Durable (p. -). Namur, Belgium. Retrieved from https://hal.archivesouvertes.fr/hal-00852513

Kelly, P. M., \& Adger, W. N. (2000). Theory and practice in assessing vulnerability to climate change andFacilitating adaptation. Climatic Change, 47(4), 325-352.

Lovelace, R. (2013). The oil vulnerability of commuter patterns: a case study from Yorkshire and the Humber, UK. Geoforum. Retrieved from http://eprints.whiterose.ac.uk/77115/

Mayer, I., Nimal, E., Nogue, P., \& Sevenet, M. (2014). The Two Faces of Energy Poverty: A Case Study of Households' Energy Burden in the Residential and Mobility Sectors at the City Level. Transportation Research Procedia, 4, 228-240. http://doi.org/10.1016/j.trpro.2014.11.018

Mignot, D., \& Aguiléra, A. (2004). Concentration et ségregation, dynamiques et inscriptions territoriales: bilan et perspectives. Revue d'Économie Régionale \& Urbaine, décembre(5), 645. http://doi.org/10.3917/reru.045.0645

Moore, R. (2012). Definitions of fuel poverty: Implications for policy. Energy Policy, 49, 1926. http://doi.org/10.1016/j.enpol.2012.01.057

Nicolas, Verry, \& Vanco. (2012). Daily trips and car use: portion of income spent on transport and household vulnerability when faced with fuel price increases. 
ONPE_PNolay. (2014, September 23). Premier rapport annuel de l'ONPE [Text]. Retrieved March 6, 2015, from http://onpe.org/rapports_de_lonpe/premier_rapport_annuel_de_lonpe

Orfeuil, J.-P. (2004). Accessibilité, mobilité, inégalités: regards sur la question en France aujourd'hui. Retrieved September 21, 2014, from http://urbanisme.upec.fr/documentation/2004-accessibilite-mobilite-inegalites-regards-sur-la-question-en-franceaujourd-hui-70567.kjsp

Palmer, G., Maclnnes, T., Kenway, P., 2008. (n.d.). Cold and Poor: An analysis of the link between fuel poverty and low income. Report New Policy Institute. Retrieved from http://npi.org.uk/publications/income-and-poverty/cold-and-poor-analysis-link-between-fuelpoverty-and-low-inc/

Proposal for Sustainable Development Goals .: Sustainable Development Knowledge Platform. (2014). Retrieved July 12, 2015, from https://sustainabledevelopment.un.org/focussdgs.html

Rao, N. D., \& Baer, P. (2012). "Decent Living" Emissions: A Conceptual Framework. Sustainability, 4(4), 656-681. http://doi.org/10.3390/su4040656

Ricci, O., \& Bérangère, L. (2014). Measuring Fuel Poverty in France: Which Households Are the Most Vulnerable?. EcoMod. Retrieved from https://ideas.repec.org/p/ekd/006356/6923.html

Roberts, D., Vera-Toscano, E., \& Phimister, E. (2015). Energy poverty in the UK: Is there a difference between rural and urban areas? (89th Annual Conference, April 13-15, 2015, Warwick University, Coventry, UK No. 204213). Agricultural Economics Society. Retrieved from http://econpapers.repec.org/paper/agsaesc15/204213.htm

Rouxel, M. (2015). Un quart des ménages bretons en situation de vulnérabilité énergétique. Retrieved from http://www.epsilon.insee.fr:80/jspui/handle/1/25973

Saujot, M. (2012). La mobilité, l'autre vulnérabilité énergétique. POLICY BRIEFS N05/2012. IDDRI, 6 P. Retrieved from http://www.iddri.org/Publications/La-mobilite,-l-autrevulnerabilite-energetique

Sen, A. (1992). The Political Economy of Targeting.

Sovacool, B. K., Cooper, C., Bazilian, M., Johnson, K., Zoppo, D., Clarke, S., ... Raza, H. A. (2012). What moves and works: Broadening the consideration of energy poverty. Energy Policy, 42, 715-719. http://doi.org/10.1016/j.enpol.2011.12.007

Sovacool, B. K., \& Dworkin, M. H. (2015). Energy justice: Conceptual insights and practical applications. Applied Energy, 142, 435-444. http://doi.org/10.1016/j.apenergy.2015.01.002

Sovacool, B. K., Ryan, S. E., Stern, P. C., Janda, K., Rochlin, G., Spreng, D., ... Lutzenhiser, L. (2015). Integrating social science in energy research. Energy Research \& Social Science, 6, 95-99. http://doi.org/10.1016/j.erss.2014.12.005

Subrémon, H. (2011). Anthropologie des usages de l'énergie dans l'habitat, un état des lieux. PUCA. Retrieved from https://hal-enpc.archives-ouvertes.fr/hal-00652414

Sustran. (2012). Locked Out: Transport Poverty in England. Retrieved July 27, 2015, from http://www.sustrans.org.uk/lockedout

Thomson, H., \& Snell, C. (2013). Quantifying the prevalence of fuel poverty across the European Union. Energy Policy, 52, 563-572. http://doi.org/10.1016/j.enpol.2012.10.009

UNDP. (2014). 2014 Human Development Report. Retrieved July 27, 2015, from http://www.undp.org/content/undp/en/home/librarypage/hdr/2014-human-developmentreport.html 
Valbonesi, P., Miniaci, R., \& Scarpa, C. (2014). Fuel poverty and the energy benefits system: The Italian case. Retrieved from http://works.bepress.com/paola_valbonesi/30

Waddams Price, C., Brazier, K., \& Wang, W. (2012). Objective and subjective measures of fuel poverty. Energy Policy, 49, 33-39. http://doi.org/10.1016/j.enpol.2011.11.095

Walker, R., Liddell, C., McKenzie, P., Morris, C., \& Lagdon, S. (2014). Fuel poverty in Northern Ireland: Humanizing the plight of vulnerable households. Energy Research \& Social Science, 4, 89-99. http://doi.org/10.1016/j.erss.2014.10.001 